\title{
CLIFF IN PIDKAMIN: ANALOGIES AND INTERPRETATIONS
}

\author{
Roman Liubun* \\ *Katedra archeológie, Filozofická fakulta, Univerzita Komenského v Bratislave, Gondova 2, 81102 Bratislava, \\ liubunroman@gmail.com
}

Abstrakt: Kameň v Pidkamine: analógie a interpretácie. Pre územie západnej Ukrajiny je charakteristická prítomnost' eróznych pieskovcových zvyškov neogénneho obdobia cenozoika. Väčšinu z nich Pudia nejakým spôsobom využívali. Jedným z najvýznamnejších objektov je Pidkamin (Lvovská oblast'). Keramický materiál potvrdzuje, že monument fungoval od doby bronzovej až do 18. storočia. Predpokladá sa, že skala slúžila ako svätyňa. Táto hypotéza bola vypracovaná na základe analýzy skalných štruktúr, ktorých analógie sú v Bulharsku.

Kl’účové slová: skalné zvyšky, západná Ukrajina, Gologoro-Kremenecké pohorie, Pidkamin, svätyna, petroglyfy

Abstract: For the territory of Western Ukraine, there is a characteristic presence of erosive sandstone remains of the Neogene period by the Cenozoic. Most of them used by people in some way. One of the most prominent objects is Pidkamin (Lviv Region). The ceramic material confirms that the monument functioned from the Bronze Age until modern times. It is believed that the rock was used as a shrine. This statement was made based on the rock structures, analogies of which are in Bulgaria.

Keywords: Rock remains, Western Ukraine, Gologoro-Kremenets ridge, Pidkamin, sanctuary, petroglyphs

https://doi.org/10.46283/musarch.2020.2.02

\section{Introduction}

Several eroded sandstone remains of the Neogene period of the Cenozoic Era are known on the territory of Western Ukraine - mainly in the areas of Eastern Carpathians, Ciscarpathians, Podilian Tovtry, and the so-called Holohoro-Kremenets ridge (Pidkamin, Tustan, Bubnyšče, Rozgirče, Ternošorska Lada, Bahna, Hrehit, Pysanyj Kamin and others). Most of them were used by the pop-

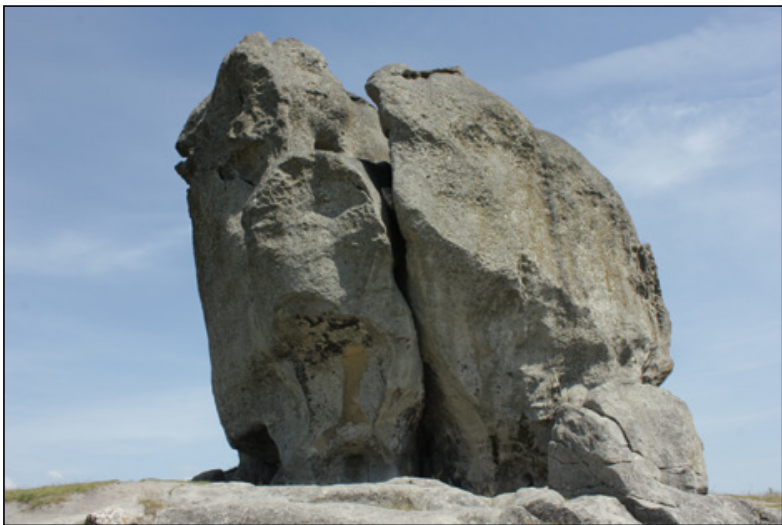

Fig. 1. Rock in Pidkamin (Photo by the author). Obr. 1. Skala v Pidkamine (foto autor). ulations of the mentioned areas in the period starting from the Bronze Age and up to the Middle Ages, which is strongly evidenced by petroglyphs, anthropogenic structures (pits, cuts, grooves, niches, wells, etc.), and the surrounding archaeological remains. Many sites remain unexplored, despite the information they can bring for the archaeology. Moreover, the existing works of Ukrainian scholars also do not give a lot of attention to these remains of stone complexes. Considering all the above mentioned, the paper aims to analyze the current state of research and possible interpretations of one of these sites - the rock remnant cliff in Pidkamin (Fig. 1) in the Lviv region. The main objectives of this study focus on the aim to clarify the chronological boundaries and func- 


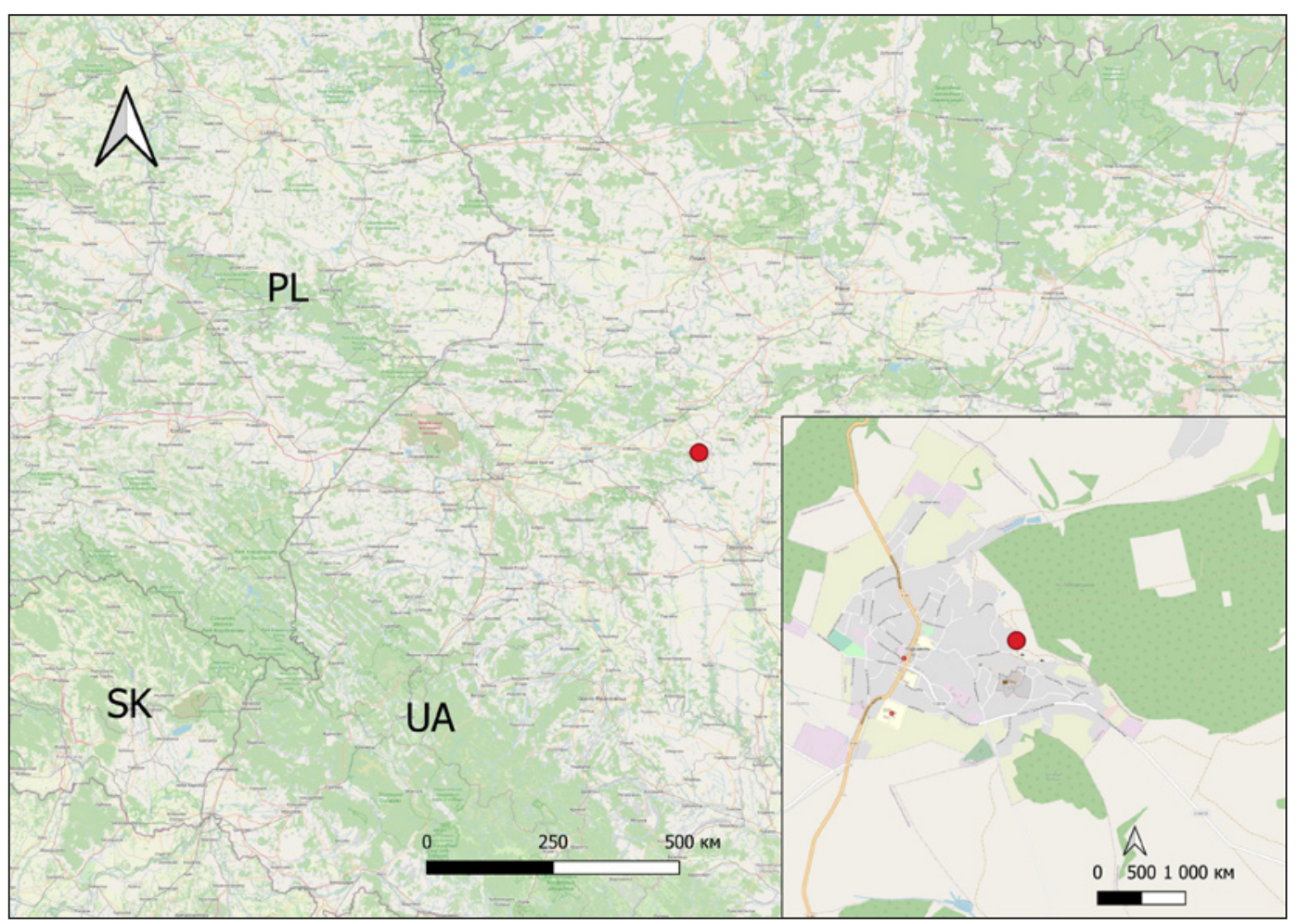

Fig. 2. Localization of Pidkamin site (created by the author).

Obr. 2. Lokalizácia Pidkaminu (vytvorené autorom).

tions of the remains connected with the cliff complex and its structures (pits, grooves, tombs, etc.). The materials used in this study were collected mainly during the exploration and excavations in Pidkamin in the 1990s. In the interpretative part, we will look at the material of more detailed studies of typologically similar South-Eastern European sites.

\section{Geographical location}

The village of Pidkamin is located in the eastern part of the Brody district of the Lviv region (Fig. 2). The site lies at the junction of the Voronyaky-Kremenets hills and occupies the part of the Volhynian-Podilian Upland ( 1 oza 2010, 9). The Voronyaky-Kremenets hills are part of the Gologoro-Kremenets ridge, which stretches from the west of the Zoločiv district, through Brody district of Lviv region, and to the Kremenets district of Ternopil region. The height of the Hologoro - Kremenets ridge does not exceed $470 \mathrm{~m}$ above sea level (Кравиук, Зінько 2018, 62). The upper reaches of the Seret and Styr rivers (103a 2010,9) heavily dissect the mountains themselves. The hilly ridges of the Medobory plateau pass from the north-west to the southeast through Pidkamin. They consist of separate ridges and cone-shaped rocky hills, which often rise above the terrain to a height of 50-60 m (103a 2010, 9). Ten kilometers west from Pidkamin, River Ikva, a tributary of the Western Bug, takes its origins. Several unnamed streams and springs surround the territory of the site.

\section{Description of the site}

The cliff complex is located in the center of the cone-shaped mountain called «Rožanytsa» or «Baba hill». The northern part of the hill has a steep slope. The southern part is a canopy, which was formed by natural landslides. 


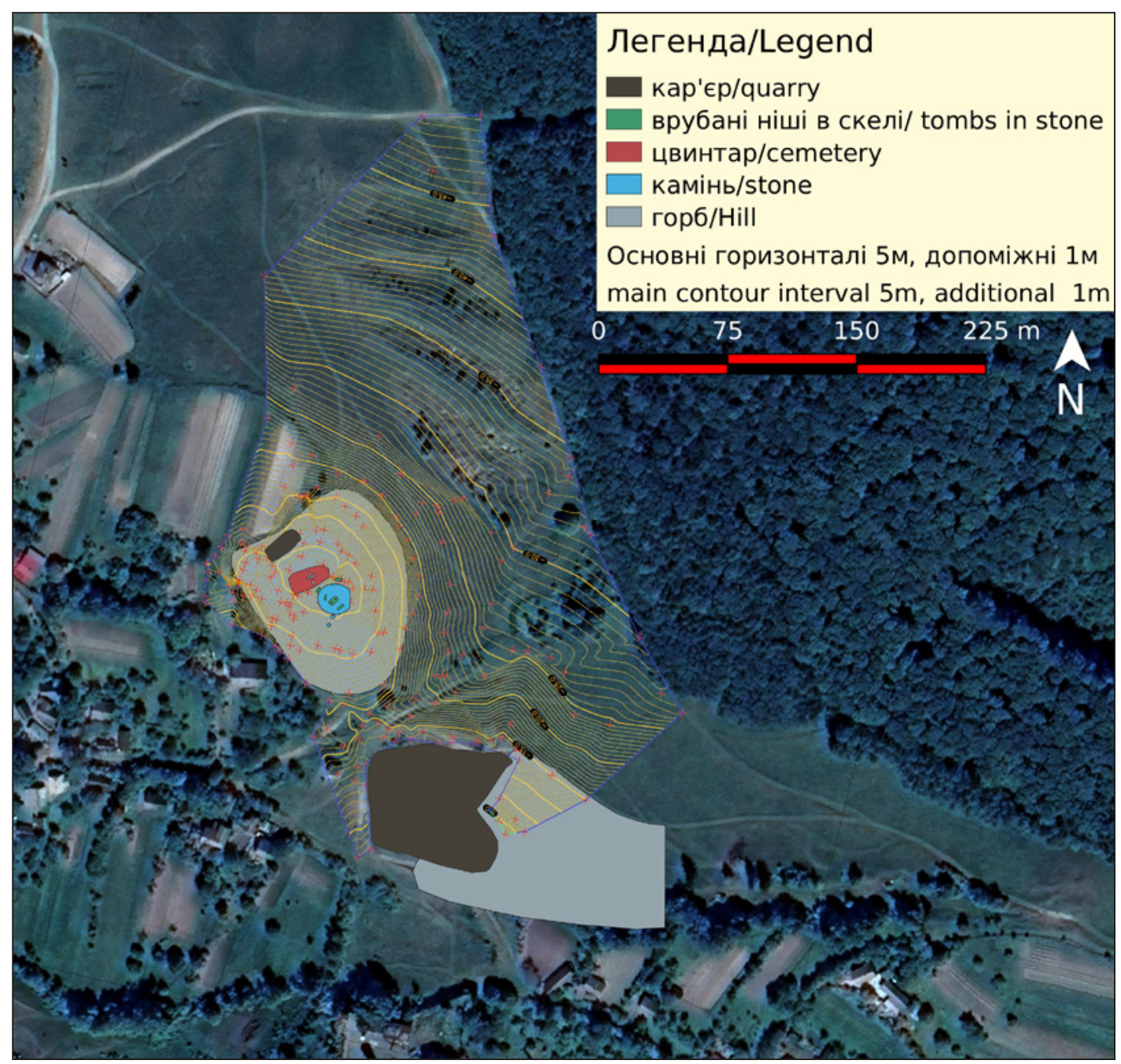

Fig. 3. Geodetic plan of the site (created by O. Didyk).

Obr. 3. Geodetický plán lokality (vytvorené O. Didykom).

A shaft (1.60 m high and $2 \mathrm{~m}$ wide) and a moat surround the cliff. The shaft and moat remain preserved only in the northern and northwestern parts of the site. Natural landslides and anthropogenic interference (Fig. 3) damage the main part of the site. Now, there was no detailed archaeological work in the tract and because of that, the dating of the shaft is unknown.

On the west side of the site, a $17-18^{\text {th }}$ century cemetery can be found with 20 stone crosses and 16 tombstones. It occupies the entire western and northwestern part of the complex and partially violates the shaft. In the southern part of the area, there are two stone objects, perhaps "altars" (?).

A $17^{\text {th }}$ century chapel is situated at the foot of the hill on its southern side and an 18th-century Dominican monastery lies on the neighboring mountain, located about $270 \mathrm{~m}$ south of the site. In the valley between the monastery and the cliff, there are caves, which in the 18th century were used as stone quarries. Their material was used to build the defensive walls of the monastery (Онищук 2010).

The cliff itself is $10.0-11.50 \mathrm{~m}$ wide and $10.0-12.70 \mathrm{~m}$ high. The sandstone remnant is divided by cracks into three unequal parts. The largest crack divides the rock structure along the axis northeast southwest. Its total height is $10 \mathrm{~m}$.

Both on the surface and at the foot of the cliff there are structures that can be classified by the following types: 1) Constructional grooves; 2) stairs; 3) cultic structures; 4) structures of unknown purpose; 5) petroglyphs. 


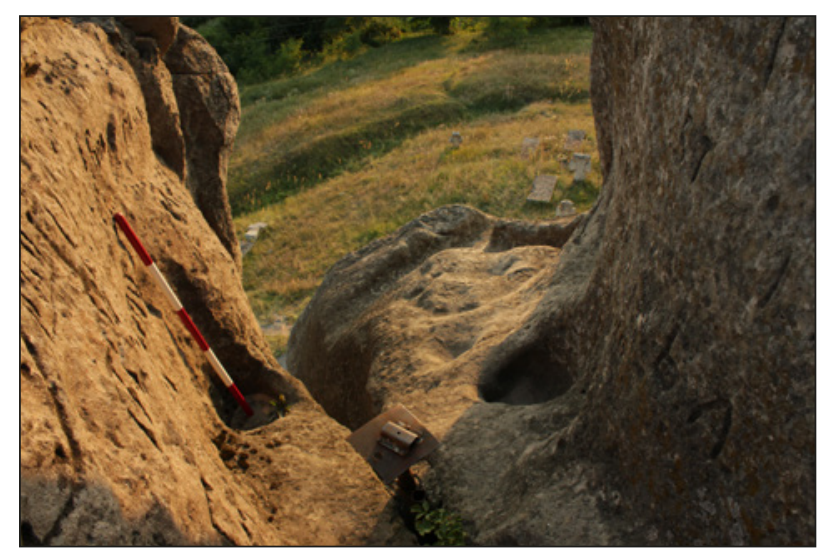

Fig. 4. Round holes № 2, 3 (Photo by O. Didyk).

Obr. 4. Okrúhle priehlbiny č. 2, 3 (foto O. Didyk).

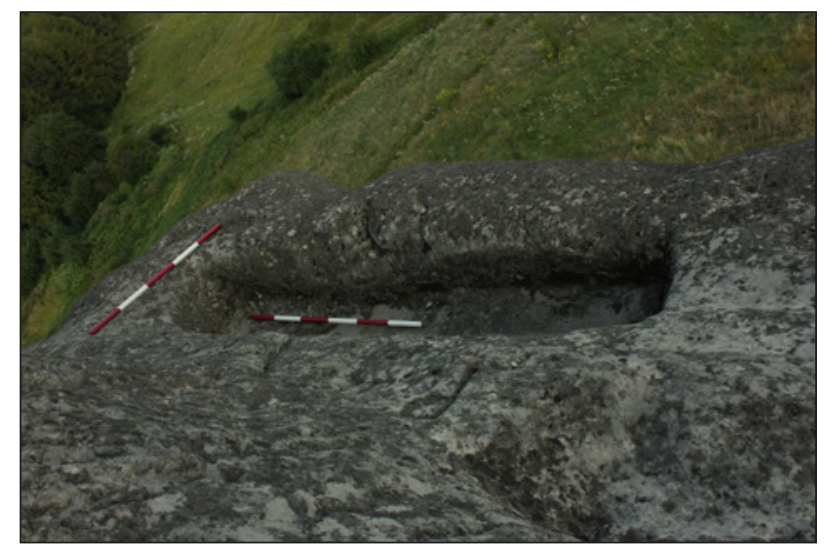

Fig. 5. Rock tomb № 1 (Photo by O. Didyk).

Obr. 5. Kamenný hrob č. 1 (foto O. Didyk).

\section{1. Constructional grooves}

Round holes on the top of cliff can be interpreted as constructional grooves. Some pits, located at the foot of the complex on the northeastern plateau are round, oval, and irregular in shape. Many shallow vertical rounded and oval-shaped pits in the northern and western parts of the cliff are objects with an unknown function.

On the top of the Cliff, five deep rounded pits can be found. Four of them are located at the top of the "Stone" on its western side and they form a row. Pit № 1 is located in the northern sector. Its diameter is $30 \mathrm{~cm}$ with $20 \mathrm{~cm}$ in depth, and the southern side beeing partially destroyed. Pit № 2 was arranged in the central sector and has $40 \mathrm{~cm}$ in diameter and $30 \mathrm{~cm}$ in depth. Pit № 3 is located at a distance of $1 \mathrm{~m}$ opposite the pit № 2 (Fig. 4), with a diameter of $30 \mathrm{~cm}$, and $20 \mathrm{~cm}$ deep. The last two holes are filled with clay. Pit № 4 is located in the southern sector (due to difficulties to access it, the measurements were not performed). Pit № 5 is found at the foot of the cliff area on the western side of the complex, with $20 \mathrm{~cm}$ diameter, and unknown depth, because currently the pit is filled with soil.

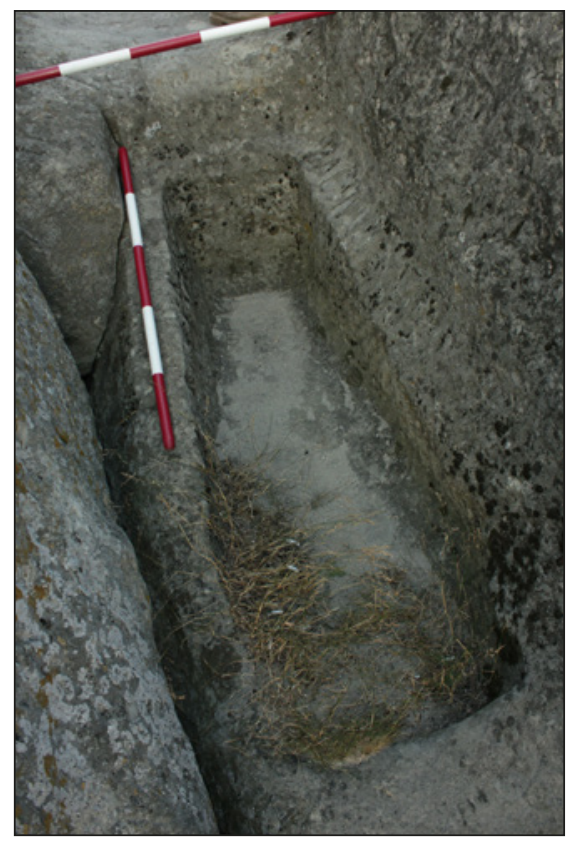

Fig. 6. Rock tomb № 2 (Photo by O. Didyk).

Obr. 6. Kamenný hrob č. 2 (foto O. Didyk).

The slots for fastening wooden structures may include two vertical grooves, $3 \mathrm{~m}$ high and $0.08 \mathrm{~m}$ wide, located parallel on the east side at the foot of the gorge. The entrance to the top is on the northeast side of the cliff, where the steps were arranged.

\section{2. Cultic structures}

Structures of this type include objects that are the so-called "rock tombs". There are four typical "rock tombs" in total and one shallow oval pit at the top of the cliff. Another "tomb" is located at the foot of the western side of the complex. They are oriented along the west-east direction.

Tomb № 1 (Fig. 5) is located in the southern sector, its length is 2.45 $\mathrm{m}$, it has $0.6 \mathrm{~m}$ in width, and $0.3-0.4 \mathrm{~m}$ in depth. Tomb № 2 (Fig. O) is located in the central sector, its length is $1,60 \mathrm{~m}$, width $-0.4 \mathrm{~m}$, depth of the western side $-0.2 \mathrm{~m}$, on the eastern $-0.45 \mathrm{~m}$. Paired tomb № 3-4 (Fig. 7) is located in the northern part of the cliff. Its total length is $2 \mathrm{~m}$, the width of the eastern side $-1.30 \mathrm{~m}$, western $-1.60 \mathrm{~m}$. It consists of southern and northern parts. The southern tomb is $2 \mathrm{~m}$ long, $0.5 \mathrm{~m}$ wide and $0.6 \mathrm{~m}$ deep. The northern tomb is $1.7 \mathrm{~m}$ long, $0.4 \mathrm{~m}$ wide and $0.4 \mathrm{~m}$ deep. In the northern sector, on the western side, there is a shallow elliptical depression. Its eastern side is $0.2 \mathrm{~m}$ wide, $0.45 \mathrm{~m}$ central, $1.20 \mathrm{~m}$ long, 


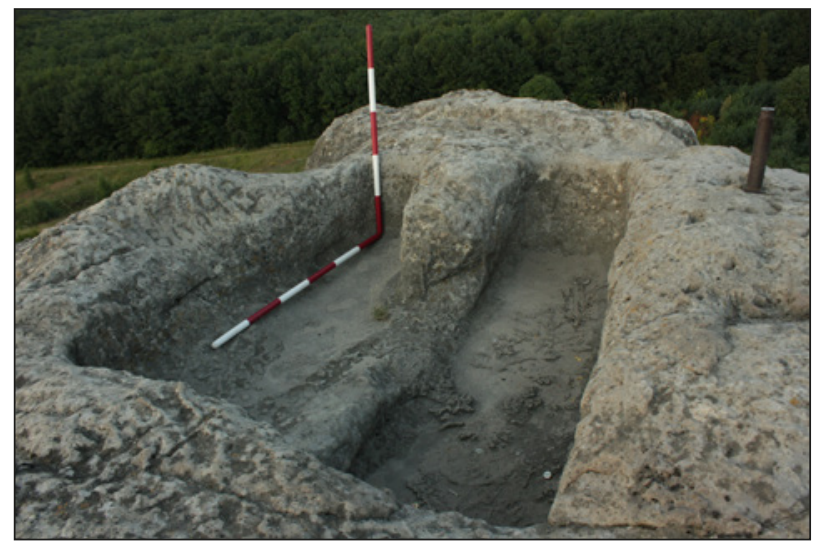

Fig. 7. Rock tomb № 3/4 (Photo by O. Didyk). Obr. 7. Kamenný hrob č. 3/4 (foto O. Didyk).

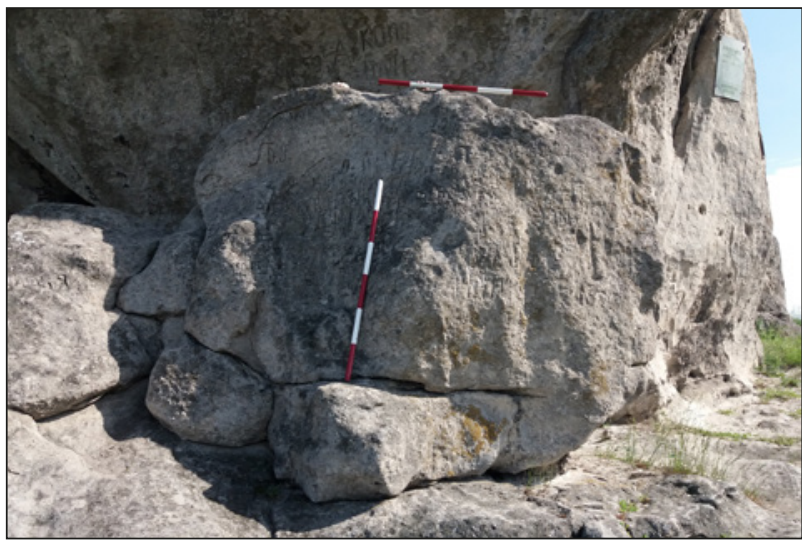

Fig. 8. Face on stone (Photo by the author).

Obr. 8. Tvár na kameni (foto autor).

and $0.10 \mathrm{~m}$ deep. The last tomb is located at the foot of the western side of the complex, $2 \mathrm{~m}$ long and $50 \mathrm{~cm}$ wide.

Niche-archosolium - At the top of the cliff, on the northwest side of the central sector a Niche-archosolium can be found. It is oriented to the southwest direction and the width of the niche is $80 \mathrm{~cm}$, height $-70 \mathrm{~cm}$, depth $-80 \mathrm{~cm}$.

"Throne"- At the foot of the southern part of the cliff site, there is a stepped structure, which resembles a seatlike structure, better known as a "Throne" (Fig. 9). The object is oriented to the west direction. Its common height is $2 \mathrm{~m}$, width $-2.3 \mathrm{~m}$. The "throne" consists of 3 steps and a backboard, which straitens to the top. The width of the upper part is $50 \mathrm{~cm}$, height $-37 \mathrm{~cm}$. The lowest step has a length of $40 \mathrm{~cm}$ and narrows downwards. The widest part has $47 \mathrm{~cm}$.

The "Throne" is situated by the side of the cliff. On the south side there is a pit $17 \mathrm{~cm}$ in diameter, and $2 \mathrm{~cm}$ in depth. On the other side of the "Throne," there is an image of the "face" (Fig. 8) that looks to the west and its height reaches $3 \mathrm{~m}$. On the east side, there is a carved cross with a height of $35 \mathrm{~cm}$.

Caves - In the valley by the western part of the cliff site, there is a deep cave (Fig. 10) where artificial niches were carved out. The largest niche (so-called "heart-shaped №2") has a heart shape (Fig. 11) and it was oriented to the west direction. The niche is $1.20 \mathrm{~m}$ wide, $1 \mathrm{~m}$ high, and $80 \mathrm{~cm}$ deep. At the bottom, the niche ends with a channel for drainage. Its length is $1 \mathrm{~m}$, width above and below $-20 \mathrm{~cm}$, in the middle $-10 \mathrm{~cm}$. On the left side, there is a small "altar"-type structure (?) $80 \mathrm{~cm}$ long and $40 \mathrm{~cm}$ wide. At the foot of the cliff, in its western part, we are still studying the following niches, gorges, and vertical pits.

"Altars"-In the southern part of the complex at the foot of the mountain two "altar" structures are located. The "altar" №1. Its length is 2.30 $\mathrm{m}$, width $-1 \mathrm{~m}$, the height of the eastern part is $1.30 \mathrm{~m}$, the western part is $1 \mathrm{~m}$. On the surface of the western part, there is a small hole of a triangular shape, $5 \mathrm{~cm}$ deep, $30 \mathrm{~cm}$ width, and with a length of $40 \mathrm{~cm}$. On the south side of the "altar", there is a vertical cut (Fig. 12) $60 \mathrm{~cm}$ high, $4 \mathrm{~cm}$ wide and $8 \mathrm{~cm}$ deep which probably has an anthropogenic origin.

The "altar" № 2. Its height is $1.70 \mathrm{~m}$, width $-1.40 \mathrm{~m}$. On the eastern side, there are 6 vertical oval holes, which served as steps (Fig. 13). On the north side, there are 3 round vertical pits. Their function is unknown. The surface of the altar is triangular. Two round horizontal holes with a diameter of $10 \mathrm{~cm}$ and a depth of $5 \mathrm{~cm}$ are visible on the surface. Totally, 9 vertical and 2 horizontal pits were found on the "altar".

Petroglyphs - Meander-shape petroglyph is located at the foot of the eastern side of the cliff (Fig. 14). Its length is $20 \mathrm{~cm}$ and width is $14 \mathrm{~cm}$. Still, the object has not been published or mentioned in the literature.

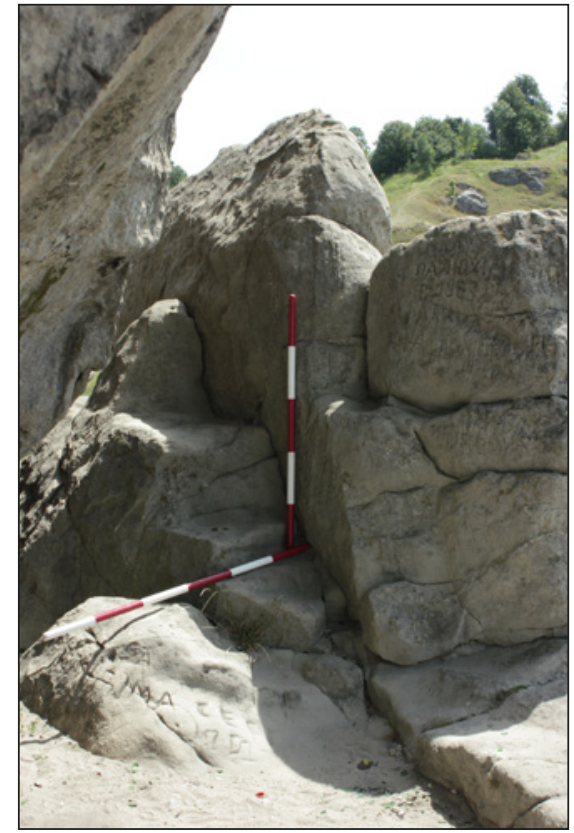

Fig. 9. Rock throne (Photo by the author).

Obr. 9. Kamenný trón (foto autor). 


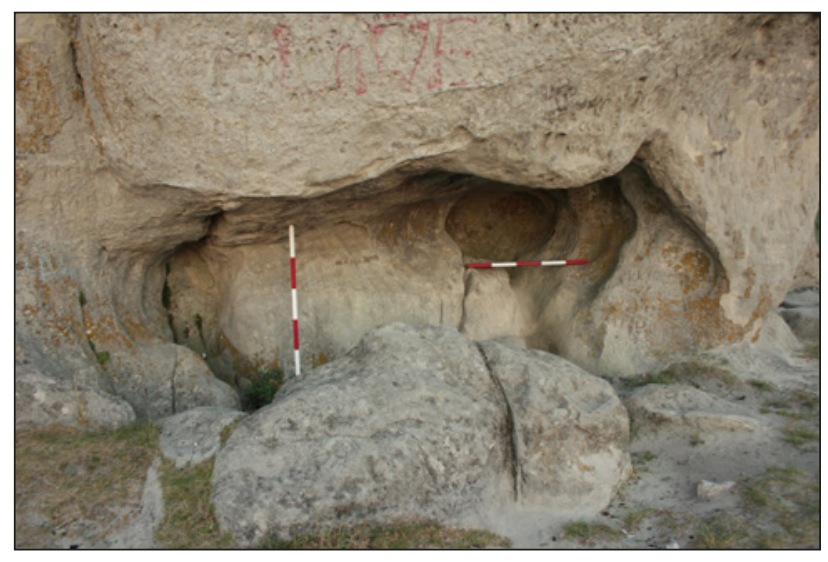

Fig. 10. Cave with nisches (Photo by the author).

Obr. 10. Jaskyňa s výklenkami (foto autor).
Compared to other inscriptions, the object is well preserved, and this calls the question of its authenticity. Another petroglyph, in the shape of a cross, is located on the south side of the cliff, in which the seat is carved.

\section{History of research}

\section{1. Archaeological research on the Cliff complex}

Despite its outstanding natural and historical heritage, the territory of Pidkamin site was studied insuf-

ficiently. We can divide the history of the study of the site into two stages. The first one can be called «Romantic». This period lasted from the late $19^{\text {th }}$ century to the early $20^{\text {th }}$ century. During the «Romantic» period, scholars have collected the legends about the stone complex and its function. The main researchers of the site were T. Zlotnitsky, T. Kunchek, J. Morachevsky, G. Stupnitsky, T. Lipinsky, and others. S. Baronch collected and arranged most of the information about Pidkamin (Рожко 1998, 115).

The second stage is more «scientific». In the 1990s M. Rožko (researcher of the cliff-side fortress «Tustan») and J. Onyščuk, were performing the main archeological work on the site. As a result, the scholars dated the cemetery and made some assumptions about the existence of a defensive church on a cliff (Рожко 1998). In 2005 R. Berest continued to research the cemetery near the stone (Береcm 2008). In 2008, the Polish organization "Magurycz" carried out some renewal work on the cemetery (Онищк 2011).

During the research work in 1997 and 2005, archaeologists found pottery that can be dated to the Late Bronze Age, the beginning of the Early Iron Age (Vysotska culture), the Middle Ages, and modern times (Онищук 2008).

Natural and climatic conditions were quite favorable for the settlement of this area from the beginning of the Mesolithic period. Within a $5-10 \mathrm{~km}$ radius from Pidkamin, there are known sites that can be dated to the Early Bronze Age (Horodok-Zdovbytsia culture), Late Bronze Age and Early Iron Age (Vysotska culture), Roman period (Wielbark culture) and the medieval Kievan Rus period (Онишук 2008). The most important site of the Bronze and Early Iron Ages is Lukašy where settlements of Horodok-Zdovbytsia and Vysotska cultures are recorded. The site is located $6 \mathrm{~km}$ north of Pidkamin site. The settlement was an important regional center of flint mining and processing (Конопля 2005, 17). Furthermore, J. Onyščuk has discovered the following new sites: Pidkamin-IV (Vysotska culture), located in the north-western part of the tract "Kamin" ("Rock"), at the foot of a hill with a stone boulder (Онищук 2008, 186); Pidkamin-II (Vysotska culture, Kievan Rus), on the south-western slope of Pidkamin mountain (Онищук 2008, 185): Pidkamin-V (settlement of the 11-12 $2^{\text {th }}$ centuries), located on the north-eastern outskirts of the village (Онимук 2008, 185).

\section{2. Hypotheses, assumptions, interpretations}

There are several main hypotheses that attempt to explain how the cliff stone complex in Pidkamin was used by the ancient populations of the region. J. Onyščuk proposed that the cliff complex perhaps was

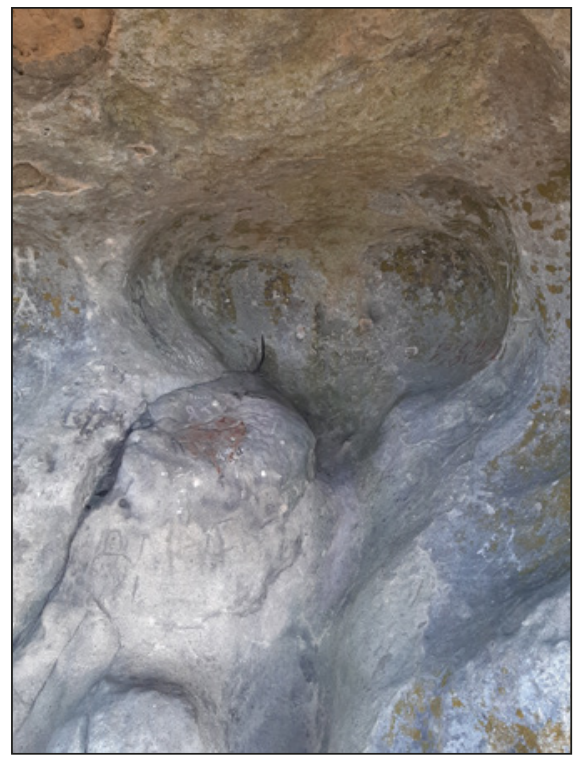

Fig. 11. Cave heart-shaped niche (Photo by the author).

Obr. 11. Jaskynný výklenok v tvare srdca (foto autor). 


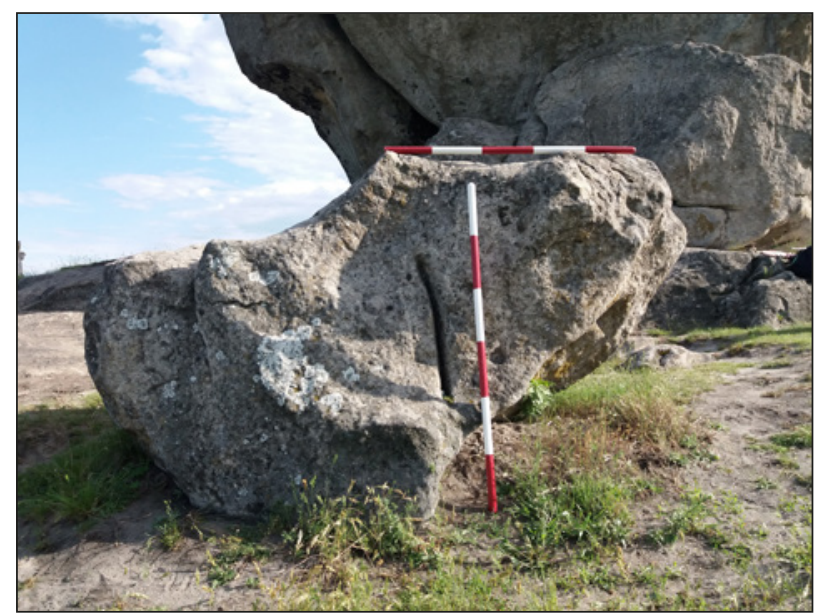

Fig. 12. Vertical cut on the altar №1 (Photo by the author). Obr. 12. Zvislý rez na oltári č. 1 (foto autor).

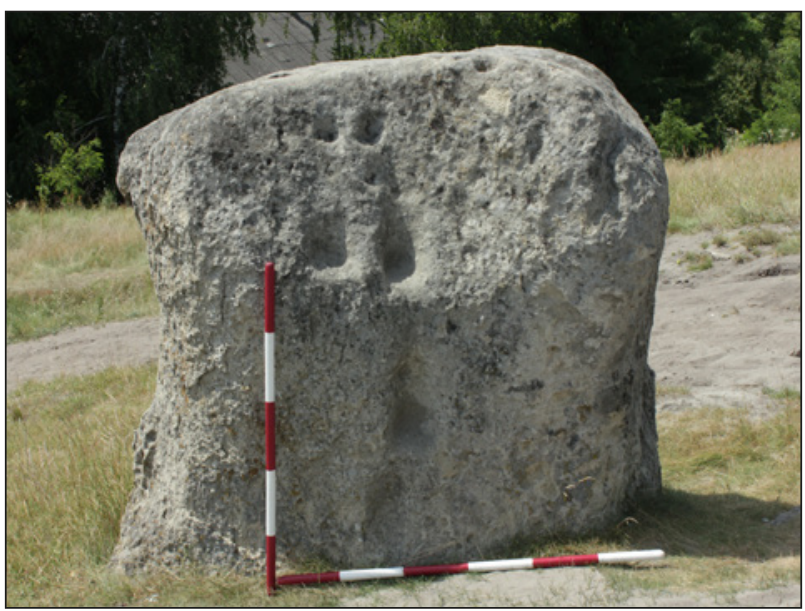

Fig. 13. Steps on the altar №2 (Photo by O. Didyk). Obr. 13. Schodíky na oltári č. 2 (foto O. Didyk).

a sanctuary of Vysotska culture, and in his opinion, this can be indicated by the found pottery fragments of this period (Онищук 2008).

M. Rožko believed that the presence of round pits and cuts on the Stone indicates the existence of a rock defensive monastery of the Kievan Rus period (Рожко 1998). The researcher pointed to the finds of ceramic tiles at the site that look quite similar to the ones that covered the floors of Galician churches in the $13^{\text {th }}$ century. S. Galaslyvy in his article provides some evidence in support of M. Rožko's version. He believes that the Church of the Transfiguration could have existed on the cliff because the construction of the Transfiguration dedicated temples on the mountains and rocks had a deep symbolic meaning. "As it is known, the Transfiguration took place on Mount Tabor, in the presence of Saint Peter. Furthermore, his name translated from Greek means cliff» (Галасливий 1999, 38).

According to M. Bandrivsky, in the 11-12 centuries the stone complex could have been used by the Cumans as a sanctuary (Бандрівський 1992). He ignores the lack of Cuman material and analyzes only the chronicles. In particular, M. Bandrivsky mentions an unknown source from 1093 CE, where a Galician prince Mykhailo Stopolk gifted some

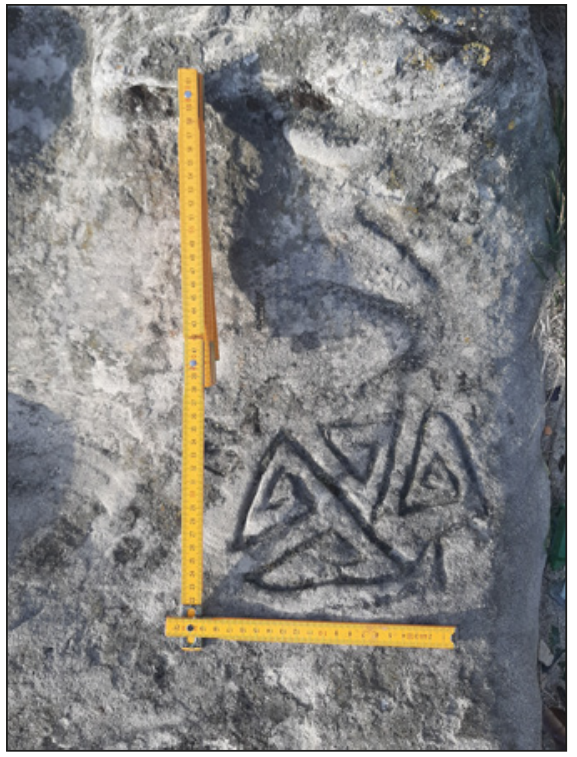

Fig. 14. Petroglyph in the shape of a meander (Photo by L. Hodovanska).

Obr. 14. Petroglyf v tvare meandra (foto L. Hodovanska). land on the borders of Red Rus and Podillya to the Cumans for their services in the conquest of Kyiv by Boleslaw the Second. In his opinion, M. Bandrivsky states that many authors, based on ancient acts that are currently unknown, identified the main estate of the Cumans mentioned in the chronicle with the area of Pidkamin cliff site (Бандрівський 1992, 85). However, S. Galaslyvy believes that these sources are not reliable. He states, that these legends were invented by the Dominican monks for the political purposes: «This fiction was needed to claim the presence (also fictional) the Dominican monks from Poland and their cultural-trigger role on the territory of Ukraine in the $13^{\text {th }}$ century» (Г аласливий 1999, 39).

The function of the cliff site in Pidkamin is still unknown, but similar rock sites from South-Eastern Europe could shed more light on this issue.

\section{Discusions}

\subsection{Use of the stone structures and their analogies}

The idea that the cliff complex probably could be used in the Late Bronze and the Early Iron Age period can be supported by the following 
evidence. First of all, a strong point is provided by the presence of the remains of this period. Based on the analysis of the found pottery material, J. Onyščuk suggests that the cliff site could be used as a pagan sanctuary site of the Vysotska culture (Онищук 2008, 185).

The second point deals with the analogies from the cult and ritual structures in Ukrainian Carpathians, and in Bulgaria (in the Rhodope Mountains, Southern Dobruja). According to Bulgarian scholars, the similarities indicate the sacred character of the complex (Fol 2008). Such sites generally belong to the Bronze Age - Iron Age period and their origin is associated with the Thracians. Here are some examples of such structures from Bulgarian rock monuments, which indicate their sacred function.

The first thing that needs to be mentioned is a "rock tbrone". There are some similar structures known from the Ukrainian territories. The only discovered analogies are the so-called "stone with a chair form", from the calendar sanctuary in Bahna (Chernivtsi region) (Марченко, Томениук 1995), "Dovbush chair" from the cut-rock complex in Gorod (Kosiv district) and another 8 chairs (Thrones) in Ivano Frankivsk region (Kyzymgk 2011). Seats-like stones were popular in the Balkan region, Western Turkey, and partly in Greece. In modern Bulgaria, such rocks remains are known from the areas near the villages Dolna Sekira and Vodna Skala, near town Strelča, at the St.Peter mountain (Mibailov 2017, 96), near village Tatul, at the sanctuary Perperek (Fol 2017, 72), at the Zalmoksis cut-rock sanctuary in Badzhali (Amaracos 2010, 235) and from other sites.

From the Republic of North Macedonia there are similar finds of the stone "thrones" in the village Kokino, and at the sanctuary Mal Surun (Temelkoski - Jandreska 2018, 56). The dating of these sanctuaries starts from the Eneolithic period and the Bronze Age. According to Macedonian researchers, a certain person, priest, or a community leader, communicated with God or performed a rite, sitting on the "throne" (Temelkoski - Jandreska 2018, 58).

In Asia Minor, the rock remains of a "throne" shape are known for the area near the ancient city of Gordion, on the sanctuary of Midas (Tamsu 2005). In Phrygia (modern Western Turkey) "thrones" served as a cult monument from the Early Phrygian period 950-800 BCE (Tamsu 2005, 441). Turkish scholars associate them with the cult of the goddess Matar. Matar is a mother goddess who originated in Anatolia since the Neolithic era. Matar is also a mountain goddess who rules over nature (Tamsu 2005, 439). Most Turkish "altar thrones" were oriented to the east, northeast, and southeast. According to Ragsan Tamsu, the fact, that the Phrygian altars are oriented to the east, makes them related to the cult of the rising sun. The rising sun is a symbol of life and the awakening of nature, the cyclical birth of the Goddess (Tamsu 2005, 441). Most of the "thrones" of the Balkan Peninsula have a similar orientation direction. There are various explanations and interpretations of this fact. It is believed, that the rays of sunlight, which are projected on a rock throne at sunrise and sunset were the symbolic equivalent of the act of fertilization or birth (Kiotsecoglou 2015).

G. Atanasov in his article "Rock cult center of Zalmoxis near the river Taban in South Dobrudzha" claims, that the throne at the sanctuary in Bajali could symbolize the divine power of Zalmoxis (Amaнacos 2010, 235). "Sitting on the symbolic throne, the spirit of Zalmoxis could observe the ceremonies at the altar, and near with his feet, people could put some sacrifices" (Amaracos 2010, 235). The symbol of the empty throne has a soteriological dimension and indicates an invitation to the deity (Mother Goddess, or other gods) to sit in a visually invisible and omnipotent presence, on the throne of "emptiness". This tradition also converted to Christianity (Kiotsecoglou 2015).

We assume that the "throne" in Pidkamin could perform a function similar to the "thrones" from Bulgarian sites. In our opinion, the spirit of the deity was sitting on the empty throne during the religious ceremonies. Perhaps a "face" carved in the southern part of the "throne" in Pidkamin provides us some possible evidence for this. Similar "faces" were found in both Bulgarian and Carpathian rock sanctuaries (Kyzymяк 2011). Another hypothetical possibility is that it was the priest who could sit on the "throne" when he watched the ceremony or headed it. The "throne" was oriented to the west direction, to the side of the sun, which in some way confirms our assumption of its cultic function.

An equally important component of Bulgarian sanctuaries is the presence of artificially carved rock niches, caves, and gorges (Amaнacoв 2010, 228). A structure similar to Pidkamin "heart-shaped niche" was discovered by the author at a rock complex in Bubnyšče. We assume, that these structures could perform certain ritual and astronomical functions (This hypothesis is based only on an assumption because no detailed research has been conducted yet). Analogies from Bulgaria provide some interesting similarities to our material. For example, many Thracian mountain sanctuaries in Bulgaria include artificial caves. Usually, some of them occupy natural cracks or faults, which artificially 
deepen into the rock. Many of them (especially from the Eastern Rhodope Mountains) clearly have the shape of the female reproductive organs (Генов 2018). Despite the fact, that the structures in Pidkamin are not classical caves, but only shallow niches and gorges, they still correspond to certain religious beliefs and traditions.

Bulgarian archaeologists proposed that the cave was associated with the birth of a deity or the female mystery of conception. The cave at the same time represented the complex nature of the Goddess. It symbolized life, death, and fertility (Генов 2018). A striking example in this regard is the cave, Tangarak Kaya. From a functional point of view, Tangarak Kaya cave can be seen as a projective system for observing an extreme culmination of the Sun. During the winter solstice, once a year, the sun's light penetrates the cave and reaches the altar (Stoev, Maglova 2018, 109). In Thracian mythology, the image of the sunlight that reaches the darkness within the cave, resembling the womb, probably can be interpreted as an image of sacred marriage, when as result, the ruler is born (Fol 2016, 71).

There are also steps and pits of various sizes, found at the sanctuaries in Bulgaria (Amaracos 2010, 228). M. Rožko connects the number of round pits at Pidkamin site with the basis of a wooden church, which we have mentioned earlier (Рожко 1999). However, we think that his idea currently needs a much more detailed analysis, both from the architectural and archaeological perspective. In our opinion, the detected number of shallow grooves could not hold massive wooden structures. Moreover, the wood has to dry and fill out, and it results in the fact that such a construction cannot be very safe and reliable. The absence of strong proofs in our opinion makes this theory quite inconclusive.

Similar structures are found not only in Pidkamin but at the sites in Ukrainian Carpathians. Analogous round pits were detected for the majority of rock-type complexes in the Northeast Balkan region (Bulgaria, Macedonia) and Asia Minor. Similar pits in Bulgaria are also considered to be the mortises for some wooden structures. According to V. Fol's hypothesis, in these "nests"/grooves people placed some sacred objects, burned a fire, or poured in the sacred liquid (Fol 2008, 160). V. Fol furthermore stated that such round pits were present on the megalithic and rock complexes in the East Mediterranean and Caucasus-Black Sea basin, including Anatolia (Fol 2008, 155).

The presence of "rock tombs" is a rare phenomenon in Bulgarian cut-rock sanctuaries. At Pidkamin there are 4 "tombs" on the top of the cliff and one tomb at its foot. The "tombs" are oriented to the west-east direction. M. Bandivsky and M. Rožko debated the interpretation of those "rock tombs" in the late $20^{\text {th }}$ century. They both dated the structures by the $11-13^{\text {th }}$ centuries and proposed that they were some kind of funeral pits. The fact they did not agree about was the cultural identification of those structures (Бандрівський 1992, 81-86; Рожко 1997, 120-121).

M. Bandrivsky supposed that the pits were used as Cuman tombs. He used the analogies of Caucasian rock tombs in the valley of the river Eskakon (Бандрівський 1992, 83) (Рунии 1970). Researchers of Caucasus region agree that this tradition appeared in the 7-8th century in the valley of the river Eskakon and spread to other areas of Caucasus under the influence of unknown Turk-speaking tribes, which forced out the Alanian population out of the area (Aлбегова 2013, 29). In the Caucasus, such tombs were used also in the period of the Alanian state in the 10-12th century (Рунич 1970).

M. Bandrivsky also mentioned the tombs from Eski-Kermen in Crimea (Бандрівський 1992, 83). At Eski-Kermen the niches often were covered by slabs and this tradition appears in the $8^{\text {th }}$ century, just at the same time as in the Caucasus. Perhaps the dead were buried in those tombs just for a while and the remains were reburied in the ground after the body had decayed (Бандрівський 1992, 83).

M. Rožko, who suggested his own ideas, criticized the conception of the presence of a Cuman sanctuary at the Pidkamin site. He thought that the pits performed the function of the church subplate burials of the $12-13^{\text {th }}$ century. The nearest analogies are found in Crimea, more precisely in the settlement of Tepsem and in the cave complexes of Mangup Kale and Tepe-Kermen (Рожко 1998, 120-121).

The interpretation of "stone tombs" depends on the general interpretation of the site and the archaeological context. Balkan cultic sites are the most interesting for us. Similar pits with quadrangular shape were found at Bulgarian rock sanctuary in Tatul (Stoev, Maglova 2015), at the stone sanctuary center in the valley of Taban (Amaracos 2010), and at the Macedonian cut-rock sanctuary Mal Surun (Stankovski - Temelkoski 2017). Archaeological excavations revealed that those sanctuaries were created at the beginning of Bronze Age and operated continuously to the medieval period.

The "Sarcophagus" from a rock sanctuary in Tatul (Bulgaria) (Stoev - Maglova 2015, 9) is a striking analogy to the material from Pidkamin. The design of the pit made it possible to cover it with a wooden plate. Scholars propose that 
the "Sarcophagus" was oriented to the specific features of the sunrise during the winter solstice. It is assumed that this fact was related to the Sun cult, and the idea that it dies and comes back to the world again (Stoev - Maglova 2015, 9).

A quadrangular pit, with a size of $1.25 \times 1.0 \mathrm{~m}$, is interpreted quite differently at the rock sanctuary of Zalmoxis in Bajaliya (Bulgaria). According to H. Atanasov, the site was created about $6-5^{\text {th }}$ centuries BCE by Thracian tribes, who begun to build rock cult constructions (Amaracos 2010, 222). The pit, hypothetically, might represent a symbolic personification of underground inhabitation (Kohajon cave), which was created by Zalmoksis, while he preached in Andreoni. Bulgarian researchers suggest that the rock pit on the east from Badjali, probably, can be understood as a symbolic and real grave of the high priest. Also, it can be attributed to "Ossuarium"-type tombs with cult objects, which usually were situated near the rock sanctuaries (Amaracoв 2010).

According to Macedonian and Bulgarian researchers, similar formations played a role of sacrificial pits for collecting liquid (Stankouski - Temelkoski 2017, 53). In the sanctuary Mal Surun (Macedonia) such pit was present on the sacrificial altar. Such structures were symbolically associated with cults dedicated to birth and farewell to life (Temelkoski - Jandreska 2018, 59).

The last known analogies are stone sanctuaries of the Iberian Peninsula. The function of "pools" that were found there is unknown and most of them are dated by pre-Roman period. Possibly some of them could be created in the Celtic period (Correia Santos 2010,155). The only existing theory of their functions is ritual use of those "pools". In the Roman age, those pits served as tombs and Latin funerary inscriptions are often found there (Correia Santos 2010).

We assume that those structures were ritual tombs of "ossuarium" type, where some sacrifices were placed or they were filled with liquid. However, we are not sure. The question of the function and dating of the rock "tombs" on the stone remains still open.

The main part of any rituals sites in Bulgaria was the altars (Amaracos 2010, 228). Stone sacrificial altars are single stones with a treated surface. Their chronology dates back to the Bronze Age. The existing finds show us that one or even more round deep formations with or without drainage grooves were carved on the older altars. They probably were used for sacrifices on specific days (Fol 2008, 156). Sacrificial altars were widely used not only in the Bronze age but by the Slavs in the early Middle Ages. Similar finds are known from the territory of Ukraine (Семениук 2018), Poland (Klimek, 2010), Belarus, Russia, and the Baltic countries (Мизина 2018).

Many sacrificial stones with pits and ditches were found in Podillya (Семениук 2018, 138). Sacrificial stones from the village of Cabanivka (Chmelnytsky region) and the village of Mižhirya (Ternopil region) are the most remarkable ones. It is assumed that the stone from the village Mižhirya could be used from the Early Iron Age until the Middle Ages (Семениук 2018, 138). Similar time frames can be set on Pidkamin. The other mentioned altars belong mainly to the period of the early medieval period and have no signs of their earlier use.

The dating of the "sacrificial altars" from Pidkamin is ambiguous. We assume that the "altar" № 1 performed its primary function from the Bronze Age to the Middle Ages. However, the "altar" № 2 during the Bronze Age could have served as a marker of the territory due to its size. According to V. Fol in the Bronze and Iron Ages in the Mediterranean and Anatolia, altars were used as symbols of territory conquered and sacralized by a particular social unit or community (Fol 2008, 156). The study of "sacrificial stones" requires a special analysis and it is possible that our assumptions will be revised.

An additional fact that indicates the cultic use of cliff site in the Early Iron Age is the presence of a meander-shaped petroglyph. The origin of the petroglyph and its dating remain unclear. Similar images of the meander are found in the ceramics of the Kalendenberg culture of the Hallstatt period of Central Europe (Schappelwein 1999). More similar drawings can be found on the clay seals from the settlements of Smolenice and Zemplin (Mirošsayová 2018). Researchers date similar motives by the dates from the end of the HaC2 (Schappelwein 1999, 216). Perhaps the petroglyph could belong to the end of $2^{\text {th }}$ and $3^{\text {th }}$ stage of the late period of Vysotska culture, which synchronically correlates with the HaC2 according to the Reinecke chronology (Бандрівський 2014, 156). However, there are serious problems with the authenticity of the petroglyph due to its state of preservation.

All the mentioned sources can indicate that in Pidkamin the cult of rock and stone was worshiped. Besides Pidkamin, in Ukraine there are many sites similar to the Bulgarian cut-rock monuments. We should mention Tustan, Bubnyšče, Ternošorska Lada, Bagna, and others (Кугymяк 2011). In our opinion, the tradition of rock complex worship in Pidkamin (including Prykarpatia) came from the Balkans at the end of Bronze Age - at the beginning of the Early Iron Age. This can be indicated mainly by the presence of the "throne", the "faces" of the deity, niche caves, 
ossuaries (?) ("rock tombs"), and other elements. Tustan perhaps could have been a similar religious rock complex site as Pidkamin. Tustan's solar signs and rock petroglyphs have broad analogies from the Balkans, the Romanian Carpathians, and the Eastern Alps (Бандрівський 1995, 9). We assume, that the cliff complex in Pidkamin clearly represents the spread of primarily Thracian ("throne", niches) and later Hallstatt (?) (Petroglyph) religious elements on the territory of the settlements of Vysotska culture.

\section{2. The site in the Middle Ages period and during the modern time}

The question of how the cliff complex was used in the Middle Ages is important but in fact, it was studied very briefly. The hypothesis of M. Rožko (the theory of the defensive church) (Рожко 1998) and M. Bandrivsky (the theory of the Cuman sanctuary) (Бандрівський 1992) require a more detailed analysis.

The most massive finds on the site are represented by pottery from the Kievan Rus period. The sacred significance of the area at this time can be evidenced by the so-called "stone with footprint". There are many legends associated with such stones, mainly about their healing qualities. The water from such a "foot" after the rain was considered to be very powerful (Бандрівський 1992, 49). A similar stone was found in a Slavic settlement-sanctuary of the $10^{\text {th }}-12^{\text {th }}$ centuries in Kulišivka (Cernivtsi region). Local inhabitants call this stone "The God's feet" (Ceмeruyk 2018, 138).

Often such things were traces of the Blessed Virgin Mary. Such a trace was also present in Pidkamin. In 1739, the monks built a chapel above the foot, which was located near the "Stone". In 1788 the shrine was moved to the church at the monastery (Бандрівський 1992, 49). This undoubtedly proves that there were 3 altars near the stone, one of which is now kept in the church as a Christian relic.

Traces of the Virgin Mary were also found at such important pilgrimage points as Počajiv and Kremenets. One of such stones is located near the monastic caves of the $13^{\text {th }}$ century and is still considered to be a shrine. According to the legend, the Virgin Mary stood with her one foot in Počajiv and with the other in Pidkamin. $5 \mathrm{~km}$ west of Pidkamin, in the village Pankivtsi, at the beginning of $20^{\text {th }}$ century another trace stone was discovered. Quoting A. Schneider, M. Bandrivsky wrote that the country folk called the stone "Probuta" or "Pierced Stone". Rainwater collected in the "foot" was believed to cure all possible diseases (Бандрівський 1992, 51).

On the top of the Stone, there is a typical for Christian religious sites niche which according to M. Rožko, served as an arcosolium (Рожко 1998, 123). Arcosolium is a niche for the installation of a sarcophagus, in medieval temples. The closest analogies were found in Crimea. M. Rožko dated it by the 12-13 century and he connected those structures with the construction of the defensive church (Рожкк 1998, 118).

The perception and function of the cliff in Pidkamin in the Modern period is problematic. From sources of the 18-19 centuries, we known that near the cliff people held their traditional meetings. There was also some kind of a "sacred grove of the Goddess" (Рожко 1998, 114). To ban such gatherings, the monks carried out propaganda against paganism. The modern toponym "Devil's Stone" is the result of the monks' activity.

For their missionary purposes in the $18^{\text {th }}$ century, the Dominicans built the monastery in Pidkamin near the famous Počajiv monastery and soon it became a place of pilgrimage. M. Rožko believed that the Pidkamin monastery was built in a place with a strong pagan tradition and the construction of the monastery was supposed to break the remaining pagan tradition in this place (Рожко 1998, 115).

The last Christian monument near Stone is an 18-century cemetery M. Rožko suggested that the cemetery has been used since the period of Kievan Rus. Probably in the $18^{\text {th }}$ century this tradition continued. According to M. Eliade, in many religions, the rock symbolized birth and death at the same time (Элuade 1999). Perhaps, the same symbolism was present in Pidkamin. The cemetery near the "Stone" clearly proves the theory of the interaction of pagan and Christian religions in this region. 


\section{Conclusions}

Our research and analysis of the cliff complex in Pidkamin proves that the site perhaps had a cultic function. The cliff and its surroundings were used from the Bronze Age to the $18^{\text {th }}$ century and the earliest dates are evidenced primarily by ceramic material. Besides that, the site features several structures typical for the Bronze Age sanctuaries in Southeastern Europe.

According to J. Onyščuk, the stone complex near Pidkamin was used as a sanctuary of the Vysotska culture. However, such cult centers in the area of distribution of this culture are still unknown. Therefore, we believe that maybe the tradition of rock site worship in the society of the Vysotska culture was borrowed or imposed by the Thracian cultures from the south, where this phenomenon was widespread. The presence of such elements as a "throne", cave niches, sacrificial stones, as well as many smaller structures have analogies at the sites in Bulgaria, Macedonia, and Asia Minor. Similar are structures also found in the Eastern Carpathians. Perhaps this is a broad regional tradition spread from the territory of South-Eastern Europe. The petroglyph in the form of a meander (special research still must be conducted to prove or disprove its authenticity) perhaps indicates contact with Hallstatt cultures of $\mathrm{HaC} 2$.

The presence of ceramics and cult structures such as the niche-arcosolium and possibly the so-called "rock tombs" states that the site was used in the medieval period. M. Rožko and M. Bandrivskyi dealt with the question of the function of the cliff complex in this time. We should note that M. Bandrivsky's theory about the "rock tombs" and the Cuman presence on the site still remains unproven and is based on analogies from the Caucasian and partly Crimean material. However, the "rock tombs" of the Pidkamin site, as we believe, have not only Caucasian but also Balkan and Mediterranean analogies, which date from the early Bronze Age to the Middle Ages. This fact highly complicates the accuracy of the presented interpretation, dating, and functions of the site. It is also difficult to agree with M. Rožko's theory that the remains were connected with a rock defensive monastery. He believed that the niche-arcosolium and the "rock tombs" were integral parts of the church, but in our opinion, the small number of round pits and vertical grooves could not hold such monumental structures. The ,rock tombs" and the arcosolium should not be associated with the church. To identify the approximate function and the chronology of the grooves and pits, a detailed archaeological and architectural study must be carried. The presence of a stone with the „foot“ of the Virgin Mary on the site also testifies to the cult use of the complex. The cult of Mary appeared here and in neighboring Počajiv in the $12^{\text {th }}$ century and still exists.

The cliff complex in Pidkamin was used as a cult place until about the $18^{\text {th }}$ century when the Dominican monks started a campaign to destroy paganism on the site. The cliff at that time received the name of "Devil's Stone", and the „foot"of the Virgin Mary was moved to a nearby church. Various legends invented by monks encouraged people to forget about the sanctity of this place and leave it.

Now Pidkamin is a place of local significance and unfortunately every year, a lot of tourists destroy the site, engraving their names on the rocks, and filling the gorges with garbage. Many possible existing petroglyphs of Hallstatt and medieval periods may be lost. The structures at the foot of the site still remain unexcavated and unexplored. The chronology, functions, and cultural aspects of the site still remain problematic and perhaps European analogies and the methods used for the study and documentation of such sites and structures might be helpful. It is equally important to map objects to determine the areas of their maximum concentration. This comprehensive approach will allow us to quickly and substantially study such cliff site structures, their approximate origin, and dating. At present, all the theories proposed by us are at the level of elaboration. Therefore, we are working fruitfully to prove or disprove the above theories in the future. Our next research will shed light on the origin of rock structures and their dating.

\section{Bibliography}

Correia Santos, M. J. 2010: Inscripciones rupestres y espacios sagrados del norte de Portugal: nuevos datos y contextualización. Los casos de Pena Escrita, Mogueira y Pias dos Mouros. Celtic Religion across Space and Time. 181-198. 
Fol, V. 2008: The rock as a topos of faith. The interactive zone of the rock-cut monuments - from Urartu to Thrace. Geoarcheology and Archaeomineralogy (Proceding of the international conference 29-30 October 2008). Sofia, 153-162.

Fol, V. 2016: The light, imaginary and real sacred space in the thracian rock - cut sanctuaries. Giving gifts to God: Evidences of votive offerings in the sanctuaries, temples and churches (International Conferences held in Skopje \& Kumanovo, 2016-2017). Skopje, 69-75.

Genov, A. 2016: Megalithic and rock-cut monuments as ritual structures related to notions of life and death and belief in eternal life and rebirth. Megalithic Monuments and Cult Practices Proceedings (Second International Symposium Blagoevgrad, 12-15 October 2016). Blagoevgrad, 323-330.

Kiotsekoglou, S. D. 2015: Thracian Megalithic Sanctuaries from the Prefecture of Evros Greece. Megalithic culture in Ancient Thrace. Blagoevgrad, 39-55.

Klimek, R. 2010: Kamienie kultowe na ziemiach Pruskich. Kamienie w historii, kulturze i religii. Olsztyn, 62-109.

Mihailov, P. 2017: Rock sanctuaries in the Struma Valley. Giving gifts to God: Evidences of votive offerings in the sanctuaries, temples and churches (International Conferences held in Skopje \& Kumanovo, 2016-2017). Skopje, 95-102.

Miroššayová, E. 2018: Sídliskové objekty vekerzugskej kultúry v povodí Laborca. Východoslovenský pravek 11, 39-73.

Schappelwein, C. 1999: Vom Dreieck zum Mäander. Untersuchungen zum Motivschatz der Kalenderbergkultur und angrenzender Regionen. Universitätsforschungen zur prähistorischen Archäologie 61. Bonn.

Stankovski, J. - Temelkoski, D. 2017: Two rocks - cut ritual complexes in the areas of Prilep and Kratovo. Giving gifts to god: evidences of votive offerings in the sanctuaries, temples and churche. (International Conferences held in Skopje \& Kumanovo, 2016-2017). Skopje, 49-58.

Stoev, A. - Maglova, P. 2015: Thracian Megalithic Sanctuaries in the Eastern Rhodopes Archaeoastronimical Aspects. Megalithic culture in Ancient Thrace. Blagoevgrad, 8-15.

Tamsu, R. 2008: Observations on The Phrygian Rock-Cut Altars. SOMA 2005 (Proceedings of the IX Symposium on Mediterranean Archaeology, Chieti (Italy), 24-26 February 2005). Chieti, 439-445.

Temelkoski, D. - Jandreska, O. 2018: Rocks used for cult purposes on the acropolis of the Mal Surun hill near the village of Dupjačani (2016 and 2017 research). Arheološkin Informator 2, Prilep, 51-59.

Aлбегова, 3. X. 2013: Археологичиские памятники Зарамагской котловины: По материалам охранных роскопок 2007-2009 гг.. Краткие сообщении института археологии 228. 3-33

Amанасов, Г. Г. 2010: Скальный культовый центр Залмоксиса у реки Табан в Южной Аобрудже. Stratum plus 6, 219-240.

Бандрівський, М. 1992: Сварожі мики. Аьвів.

Бандрівський, М. 1995: Місце петрогліфів Уріча в наскельному мистецтві Карпато-Балканського регіону. Скелі й печери в історії та культурі стародавнього населення України. Аьвів. 7-10. 
Бандрівський, М. 2014: Культурно-історичні процеси на Прикарпатті і ЗахіАному Поділмі в пізній період епохи бронзи на початку доби раннього заліза. Аьвів.

Берест P. 2008: АосліАження монастиря в селищі ПіАкамінь на Аьвівщині. Матеріали і досліАження з археології Прикарпаття і Волині. Вип. 12., 360-367.

Войнаровський, В. - Конопля, В. - Филипчук, М. 2005: Аукаші. Багатошарова пам’ятка археології на БріАщині. $\Lambda$ ьвів.

Галасливий, С. 1999: Монастирі ПіАкаменя. Аавра 1. Київ, 38-41.

Генов, А. 2018: Обожествената природа. Сакрализираните пешери като алегория на отвъдното. Thracia XXIII Thraco-Anatolica. Sofia, 189-200.

Кравиук, Я. - Зінько, Ю. 2018: Рель’еф Аьвівської області. Аьвівська область: Природні умови та ресурси. Аьвів, 55-85.

Kyzymяк, M. 2011: Сакральна спадщина Гуцульщи. Старожитності Гуцульщини джерела з етнічної історії населення українських Карпат 1. Івано-Франківськ.

Аоза, Б. 2010: Природа БріАщини. Броди.

Марченко. Г. - Томениук. Б. 1995: Скельне календарне святилище біля села Багна Чернівецької області. Скелі й печери в історії та культурі стародавнього населення України. $\Lambda$ ьвів. 54-56.

Мизина, В. Г. 2018: Культовые камни Восточной Европы: Беларусь, Аатвия, Аитва, Россия. Санкт-Петербург.

Онимук, Я. 2008: Археологічні пам'ятки Бродівського району мьвівської області (за матеріалами Бродівського історико-краєзнавчого музею). Археологічні дослідження мьвівського університету 11. Аьвів, 172-194.

Онищук, Я. 2010: ПіАкамінські печери: спроба історичної інтерпретації. Наукові записки 8. Рівне, 240-243.

Онмиук, Я. 2011: Ао питання хронології християнських поховань в урочищі «Камінь» у ПіАкамені. БріАщина край на межі Галичини та Волині 4. (Матеріали п'ятої краєзнавчої конференції, присвяченої дню пам'яток історії та культури). Броди, 35-38.

Рожко, М. 1998: Скельні групи медоборів та використання ї у минулому. Медобори і духовна культура Аавніх, середньовічних слов’ян (Матеріали наукової конференції до 150 - річчя виявлення 3бруцького Святовита). Аьвів, 113-124.

Рожко, М. 1999: Про Аеякі оборонні Преображенські монастирі XIII ст. в Галичині. Аавра 1. Київ, 42-49.

Рунич А. П 1970: Катакомбы Рим горы. Советская Археология 2, 198-211.

Семенчук, С. 2018: Осередки язичництва Аівобережжя Середньої Подністрянщини (XI ст. Ао н.е. - XIII ст. н.е.). Аисертація. Кам’янець-ПодіАьський.

Элиаде, М. 1999: Тайные общества Обряды инициации и посвящения. Пер. с фр. Г. А. Гельфанд. Москва Санкт-Петербург. 


\section{Appendix}

Here are available 3D models of stone structures (author of models: O. Didyk), see the following links (retrieved 2020, September 30):

Rock-tomb № 2:

https://p3d.in/1poZf?fbclid=IwAR0MTGAtvAKFuxZYe3jijoj5BkPwoDu5JR5Db8XW1ixCl4S4XGQXF46-6B8

Rock-tomb № 3\4:

https://p3d.in/aGIIU?fbclid=IwAR2LFNw24P-k2elsGKfZqatcGT1V93DKLOsi5R6KxjGAF2siCgPjpDz96E4

Altar № 1:

https://p3d.in/0N40X?fbclid=IwAR1Skoykyq3N3sePkLdEqrjdTzWoZkpyTBqb2x17XqtgpfwMwEqgtz6gr2Y

Altar № 2:

https://p3d.in/31Qxj?fbclid=IwAR3ZQ7QtQLbI_a-R8tqjjucnYKpTRwppAJATdotBfaoyHCfOqzy0IxU5uKU

Cave niches:

https://p3d.in/odsTv

\section{Zhrnutie}

Náš výskum a analýza skalného komplexu v Pidkamine (obr. 1) v L’vovskej oblasti na západnej Ukrajine dokazujú, že miesto malo pravdepodobne kultovú funkciu. Lokalita a jej okolie boli využívané od doby bronzovej až do 18. storočia, pričom najstaršie datovanie potvrdzuje predovšetkým keramický materiál. Okrem toho sa na lokalite nachádza niekol'ko štruktúr typických pre svätyne z doby bronzovej v juhovýchodnej Európe. Podl’a J. Onyščuka sa kamenný komplex ned’aleko Pidkamina využíval ako svätyňa vysotskej kultúry. Takéto kultové centrá v oblasti rozšírenia tejto kultúry sú však stále neznáme. Preto sa domnievame, že možno tradíciu uctievania skalných lokalít v spoločnosti vysotskej kultúry smeruje k územiu Trákov, kde bol tento fenomén rozšírený. Prítomnost’ prvkov ako „trón“, jaskynné výklenky, obetné kamene, ako aj vel’a menších štruktúr majú obdoby v lokalitách v Bulharsku, Macedónsku a Malej Ázii. Podobné sa nachádzajú aj vo Východných Karpatoch. Predpokladáme, že by mohlo íst' o širokú regionálnu tradíciu šíriacu sa z územia juhovýchodnej Európy. Petroglyf vo forme meandra (stále je potrebné vykonat' špeciálny výskum s ciel'om dokázat' alebo vyvrátit' jeho autenticitu) možno naznačuje kontakt s halštatskými kultúrami v období HaC2. Prítomnost' keramiky a kultových štruktúr, ako napríklad arkozólia a takzvané „skalné hrobky“ poukazujú na využívanie lokality v období stredoveku. Otázkou funkcie skalného komplexu sa zaoberali M. Rožko a M. Bandrivskyi. Je nutné poznamenat', že teória M. Bandrivského o „skalných hrobkách“ a kumánskej prítomnosti na tomto mieste stále nie je dokázaná a je založená na analógiách z kaukazského a čiastočne krymského materiálu. Avšak „skalné hrobky“ lokality Pidkamin, ako sa domnievame, majú nielen kaukazské, ale aj balkánske a stredomorské analógie, ktoré poznáme od staršej doby bronzovej do stredoveku. Táto skutočnost’ ovplyvňuje výsledné interpretácie, datovanie a predpokladané funkcie objektov. Taktiež t’ažko možno súhlasit’ s teóriou M. Rožka, ktorý tvrdí, že pozostatky boli spojené so skalným obranným kláštorom. Podl’a nášho názoru malý počet okrúhlych jám a zvislých drážok nesúvisí s takými monumentálnymi stavbami. Na identifikáciu približnej funkcie a chronológie žliabkov a jám je potrebné vykonat’ podrobnú archeologickú a architektonickú štúdiu. O kultovom využití komplexu svedčí aj prítomnost’ kameňa so „stopou“ Panny Márie. Kult Márie sa tu a v susednom Počajive objavil v 12. storočí a stále existuje.

Komplex v Pidkamine sa používal ako kultové miesto až do približne 18. storočia, kedy dominikánski mnísi začali viest' aktivity za zničenie pohanstva na tomto mieste. Miesto dostalo v tom čase meno „Čertov kameň“ a „stopa“ Panny Márie bola premiestnená do ned’alekého kostola. Rôzne legendy, ktoré vymysleli mnísi, povzbudzovali l’udí, aby zabudli na posvätnost' tohto miesta a opustili ho. Teraz je Pidkamin miestom lokálneho významu a jeho súčasný stav negatívne ovplyvňuje návštevnost' a rôzonorodé zásahy l'udí, ktorí na skaly gravírujú svoje mená a miesto zapĺn̆ajú odpadkami. 
Štruktúry na úpätí miesta stále zostávajú nevykopané a nepreskúmané a lokalita si vyžaduje komplexný výskum. V budúcnosti bude dôležité identifikovat' a mapovat' podobné pamiatky a oblasti ich maximálnej koncentrácie v okolitých územiach a v juhovýchodnej Európe. Tento komplexný prístup nám umožní detailne študovat' podobné útvary, ich počiatky a datovanie. V súčasnosti sú všetky nami navrhované teórie na úrovni rozpracovania a verifikácie. Náš d'alší výskum je zameraný na výskum pôvodu horninových štruktúr a ich datovanie. 